\title{
CrimRxiv
}

\section{Trauma Center Drive Time Distances and Fatal Outcomes among Gunshot Wound Victims}

Giovanni Circo, Andrew Wheeler

Published on: Jun 28, 2021

DOI: 10.21428/cb6ab371.256b7d14

License: Creative Commons Attribution 4.0 International License (CC-BY 4.0). 
